\title{
Intensive ground vegetation growth mitigates the carbon loss after forest disturbance
}

\author{
Bernhard Zehetgruber • Johannes Kobler • Thomas Dirnböck • \\ Robert Jandl • Rupert Seidl • Andreas Schindlbacher
}

Received: 21 February 2017 / Accepted: 11 August 2017 /Published online: 24 August 2017

(C) The Author(s) 2017. This article is an open access publication

\begin{abstract}
Aims Slow or failed tree regeneration after forest disturbance is increasingly observed in the central European Alps, potentially amplifying the carbon (C) loss from disturbance. We aimed at quantifying $\mathrm{C}$ dynamics of a poorly regenerating disturbance site with a special focus on the role of non-woody ground vegetation.

Methods Soil $\mathrm{CO}_{2}$ efflux, fine root biomass, ground vegetation biomass, tree increment and litter input were assessed in (i) an undisturbed section of a $\sim 110$ years old Norway spruce stand, (ii) in a disturbed section which was clear-cut six years ago (no tree regeneration), and (iii) in a disturbed section which was clear-cut three years ago (no tree regeneration).
\end{abstract}

Electronic supplementary material The online version of this article (https://doi.org/10.1007/s11104-017-3384-9) contains supplementary material, which is available to authorized users.

B. Zehetgruber $\cdot$ R. Jandl $\cdot$ A. Schindlbacher $(\bowtie)$

Department of Forest Ecology, Federal Research and Training Centre for Forests, Natural Hazards and Landscape - BFW, Seckendorff-Gudent Weg 8, A-1131 Vienna, Austria

e-mail: andreas.schindlbacher@bfw.gv.at

J. Kobler · T. Dirnböck

Department for Ecosystem Research and Environmental Information Management, Environment Agency Austria, Spittelauer Lände 5, A-1090 Vienna, Austria

R. Seidl

Institute of Silviculture, Department of Forest and Soil Sciences, University of Natural Resources and Life Sciences (BOKU)

Vienna, Peter Jordan Straße 82, 1190 Wien, Austria
Results Total soil $\mathrm{CO}_{2}$ efflux was similar across all stand sections $\left(8.5 \pm 0.2\right.$ to $\left.8.9 \pm 0.3 \mathrm{t} \mathrm{C} \mathrm{ha}^{-1} \mathrm{yr}^{-1}\right)$. The undisturbed forest served as atmospheric $\mathrm{C}$ sink (2.1 t C ha ${ }^{-1} \mathrm{yr}^{-1}$ ), whereas both clearings were $\mathrm{C}$ sources to the atmosphere. The source strength three years after disturbance $\left(-5.5 \mathrm{t} \mathrm{C} \mathrm{ha}^{-1} \mathrm{yr}^{-1}\right)$ was almost twice as high as six years after disturbance $(-2.9 \mathrm{t} \mathrm{C}$ $\left.\mathrm{ha}^{-1} \mathrm{yr}^{-1}\right)$, with declining heterotrophic soil respiration and the high productivity of dense graminoid ground vegetation mitigating $\mathrm{C}$ loss.

Conclusions $\mathrm{C}$ loss after disturbance decreases with time and ground vegetation growth. Dense non-woody ground vegetation cover can hamper tree regeneration but simultaneously decrease the ecosystem $\mathrm{C}$ loss. The role of ground vegetation should be more explicitly taken into account in forest $\mathrm{C}$ budgets assessing disturbance effects.

Keywords Disturbance - Clear-cut · Fine roots . Forest $\mathrm{C}$ cycling $\cdot$ Ground vegetation $\cdot$ Soil $\mathrm{CO}_{2}$ efflux

\section{Introduction}

Despite a growing number of silvicultural alternatives clear-cutting is still the most common harvesting practice and represents one of the primary anthropogenic disturbance regimes in many forest ecosystems (Puettmann et al. 2015). Furthermore, natural disturbance regimes such as windthrow or bark beetle infestations are common in many forest ecosystems, and may intensify under climate change (Seidl et al. 2014a). 
Forest management often salvages trees from these naturally disturbed sites, further enlarging their areal extent. Stand replacing disturbances therefore play a particularly important role in shaping forest landscapes. The combination of natural and anthropogenic disturbances results in forest landscapes structured by cleared areas of varying sizes, from several square meters to square kilometers (Franklin et al. 2002; Mitchell 2013; Senf et al. 2017). Consequently, stand-replacing disturbances are major drivers of the forest $\mathrm{C}$ cycle, and have important implications in the context of climate change mitigation (Canadell and Raupach 2008).

Forest clearings, whether of natural or anthropogenic origin, loose C to the atmosphere (Odum 1969; Körner 2003; Amiro et al. 2010; Goetz et al. 2012). C uptake by the vegetation is largely diminished after disturbance, whereas $\mathrm{C}$ loss from debris and the forest soil continues, or even increases when compared to pre-disturbance conditions (Knohl et al. 2002; Kurz et al. 2008; Amiro et al. 2010; Pfeifer et al. 2011). How long a disturbed forest acts as a $\mathrm{C}$ source depends on the severity of the disturbance, biological legacies, and the regeneration potential of the vegetation (Brown et al. 2010, 2012; Mathys et al. 2013; Seidl et al. 2014b). Furthermore, it is crucial how the decomposition of soil organic matter (SOM) is affected (Nave et al. 2010; Köster et al. 2011; Don et al. 2012). If environmental conditions become more favorable as a result of the disturbance, i.e. warmer and/ or wetter, the decomposition of SOM can be enhanced and the soil $\mathrm{CO}_{2}$ efflux (= soil respiration; $\mathrm{R}_{\mathrm{s}}$ ) increased (Morehouse et al. 2008; Mayer et al. 2014). The time until a cleared temperate forest returns to a net $\mathrm{C}$ sink is largely determined by the speed and extent of tree regeneration (Edburg et al. 2012; Hansen 2013), and typically ranges from 5 to 20 years (Romme et al. 1986; Kolari et al. 2004; Luyssaert et al. 2007; Amiro et al. 2010; Hansen 2013). However, for a number of reasons, delayed tree regeneration after disturbance can occur. In many European forests, for instance, ungulate browsing pressure is high (Reimoser and Reimoser 2010; Schodterer 2011). Therefore, the regeneration of disturbed areas can be delayed, especially if the subsequent establishment of dense ground vegetation inhibits tree regeneration (Ammer 1996; Reimoser and Gossow 1996). This imposes the risk of massive C loss from the ecosystem (Knohl et al. 2002; Mayer et al. 2014), yet at the same time prolific ground vegetation might also take up and store significant amounts of C.

We conducted a case study in a mature montane Norway spruce forest in the Austrian limestone Alps aiming at quantifying $\mathrm{C}$ dynamics after clear-cutting with a special emphasis on noon-woody ground vegetation. In a prior study, Kobler et al. (2015) showed that a mature Norway spruce forest in the area serves as net $\mathrm{C}$ sink. We hypothesized that clear-cutting turns the forest into a substantial temporal atmospheric $\mathrm{C}$ source as a result of ceased $\mathrm{C}$ uptake by trees and more favorable environmental conditions for SOM decomposition (warmer soil). We further hypothesized that $\mathrm{C}$ input from fast establishing non-woody ground vegetation mitigates a part of the $\mathrm{C}$ loss from the clear-cut areas over time.

\section{Materials and methods}

Site description

The study was conducted at the Austrian long-term ecosystem research and monitoring (LTER) site "Zöbelboden", located in the National Park "Northern Limestone Alps" (N 47 50'30", E 14²6' $\left.30^{\prime \prime}\right)$. The site is characterised by cool, humid climate with maximum precipitation in summer (mean annual temperature and precipitation $1996-2011$ were $7.8^{\circ} \mathrm{C}$ and $1645 \mathrm{~mm}$, respectively). The snow-free period lasts from March to December. The study site is located at about $950 \mathrm{~m}$ a.s.l. with moderate slopes exposed in N/NW/W directions. Soil types are highly spatially variable, and consist of Lithic to Rendzic Leptosols and Chromic Cambisols with partly stagnic characteristics (WRB 2006). The underlying bedrock is dolomite.

\section{Study design}

We used the study site's forest monitoring plots (Hülber et al. 2008) and disturbance maps derived from aerial photographs and field surveys to locate a disturbance chronosequence which is representative as to its tree and herbaceous layer characteristics. The studied forest consisted of the following sections: (i) an undisturbed mature forest stand (hereafter MS); (ii) a six years old clearing with no tree regeneration (hereafter PD06); and 
(iii) a three years old clearing with no tree regeneration (hereafter PD03).

After clear-cutting in 1910, Norway spruce (Picea abies (L.) Karst.) was regenerated by planting to form the $\sim 110$ years old mature forest stand $(\sim 5 \mathrm{ha})$. The stand was located at a gently sloped, homogenous plateau-top exposed in N/NW direction. The undisturbed section $(\sim 3.5 \mathrm{ha})$ of the mature forest represented MS in our study. In 2007 and 2008, a section of the stand was hit by storms. Trees broken by wind were salvaged 2008, causing a cleared area of approximately $\sim 0.5$ ha. Harvest residues were left on site. Until the study year 2014, no tree regeneration had established at this clear-cut section (PPD 06), which was covered by dense grassy ground vegetation with a height of $>1 \mathrm{~m}$ during peak growth. A further section of the stand was disturbed in 2011 following bark beetle infestation. Visibly infested and surrounding trees were felled and the stems were removed, leaving a cleared area of $\sim 1$ ha. Harvest residues were left on site as in PD06. The 2011 clearing (PD03) showed no tree regeneration and only moderate herbaceous ground vegetation cover. The direct spatial vicinity of the undisturbed stand and the two clearings ensured uniform site and soil conditions. Detailed characteristics of the different stand-sections are presented in Table 1. An areal overview of the different stand section is provided in Fig. A1.

Soil respiration, temperature and moisture measurements

At all stand-sections, soil $\mathrm{CO}_{2}$ efflux $\left(\mathrm{R}_{\mathrm{s}}\right)$ was measured from 12 randomly distributed plots. Each $1 \times 1 \mathrm{~m}$ plot was equipped with a single collar for $\mathrm{R}_{\mathrm{s}}$ measurements (10 cm diameter, $4 \mathrm{~cm}$ height, center of the plot). The PVC collars were inserted $2 \mathrm{~cm}$ into the ground. $\mathrm{R}_{\mathrm{s}}$ was measured every three weeks from March 2014 to November 2014. $\mathrm{R}_{\mathrm{s}}$ was measured with a portable infrared gas analyzer (EGM-4) and an attached chamber (SRC-1) (PP Systems International, Inc. Amesbury, MA, USA). The chamber closure time was $120 \mathrm{~s}$. $\mathrm{R}_{\mathrm{s}}$ was calculated automatically by fitting a quadratic function to the increasing $\mathrm{CO}_{2}$ headspace concentration. Soil respiration measurements of all chambers were completed within $8 \mathrm{~h}$. To assure a consistent measurement protocol, the $\mathrm{R}_{\mathrm{s}}$ measurements started between 9:00 and 10:00 a.m. and the collars were measured in random order.
Adjacent to the $\mathrm{CO}_{2}$ chamber soil temperature and soil moisture were recorded at the time of $R_{s}$ measurement. Soil temperature was measured at $5 \mathrm{~cm}$ soil depth using a handheld temperature probe. Soil moisture was recorded at a soil depth of $0-15 \mathrm{~cm}$ using a Time Domain Reflectometry (TDR) unit (model 6050X1, Soil Moisture Equipment Corp., CA, USA) equipped with $15 \mathrm{~cm}$ long stainless steel rods. TDR measurements were carried out at three random locations at each of the 12 plots. Additionally, we buried between four and five permanent temperature data loggers (iButton ${ }^{\circledR}$ devices, Maxim Integrated, San Jose, CA, USA) at each stand-sections at $5 \mathrm{~cm}$ soil depth in Nov 2013. Using these data loggers, soil temperature was continuously recorded in an interval of three hours until Nov 2014.

To estimate the contribution of autotrophic respiration to the soil $\mathrm{CO}_{2}$ efflux we followed two approaches. We used already existing trenching plots (Kobler et al. 2015) to estimate the autotrophic $\left(R_{a}\right)$ and heterotrophic $\left(R_{h}\right)$ contribution to $R_{s}$ in the mature stand. To estimate $R_{a}$ from the dense herbaceous and grass vegetation, we established clipping plots at PD06. About $3 \mathrm{~m}$ away from each of the collars for periodic $\mathrm{CO}_{2}$ measurements, random areas of $1 \mathrm{~m}^{2}$ were clipped, resulting in a total of 12 clipping plots. All aboveground plant components were clipped and removed from the plots and a collar was placed in the center of each clipping plot for $\mathrm{R}_{\mathrm{s}}$ measurements. Clipping was repeated one day before each $\mathrm{CO}_{2}$ measurement campaign. Fern mats (side length: $0.3 \mathrm{~m}$, height $0.2 \mathrm{~m}$ ) were placed in a bow above the collars to produce shade and to avoid soil heating at the clipped plots. The clipping experiment started with vegetation growth in May. The method aimed at removing all above ground vegetation components, and thus excluding the transport of newly assimilated carbohydrates to the roots. We observed that even repeated clipping did not kill the ground vegetation. Hence, a portion of the roots likely remained active, especially during the earlier stages of the clipping experiment (Högberg et al. 2001; Zhou et al. 2007). Therefore, only the difference between the soil $\mathrm{CO}_{2}$ efflux from untreated and clipped plots during the latter part of the study year was used as a proxy of $R_{a}$. Due to limited labour resources, we did not clip at PD03. For PD03, we estimated the autotrophic contribution by using the relationship between fine root carbon $(f$ 
Table 1 Vegetation and soil characteristics

\begin{tabular}{|c|c|c|c|}
\hline Stage/stand-section & Mature stand (MS) & 2011 clearing (PD03) & 2008 clearing (PD06) \\
\hline \multicolumn{4}{|l|}{ Trees } \\
\hline \multirow[t]{3}{*}{ Tree species } & Norway spruce (Picea abies (L.) Karsten) & & \\
\hline & European larch (Larix decidua Mill.) & & \\
\hline & European beech (Fagus sylvatica L.) & & \\
\hline Basal area $\left[\mathrm{m}^{2} \mathrm{ha}^{-1}\right]$ & 65.3 & & \\
\hline \multicolumn{4}{|l|}{ Herb layer } \\
\hline \multirow[t]{4}{*}{ Dominant species } & $\begin{array}{l}\text { Calamagrostis varia (Schrad.) } \\
\text { Host. }\end{array}$ & $\begin{array}{l}\text { Cirsium arvense (L.) } \\
\text { Scop. }\end{array}$ & $\begin{array}{l}\text { Calamagrostis epigejos } \\
\text { (L.) Roth }\end{array}$ \\
\hline & $\begin{array}{l}\text { Brachypodium sylvaticum (Huds.) } \\
\text { PB. }\end{array}$ & $\begin{array}{l}\text { Calamagrostis epigejos } \\
\text { (L.) Roth }\end{array}$ & $\begin{array}{l}\text { Calamagrostis varia } \\
\text { (Schrad.) Host. }\end{array}$ \\
\hline & $\begin{array}{l}\text { Hordelymus europaeus (L.) } \\
\text { Jessen ex Harz }\end{array}$ & $\begin{array}{l}\text { Calamagrostis varia } \\
\text { (Schrad.) Host }\end{array}$ & Carex alba Scop. \\
\hline & $\begin{array}{l}\text { Senecio ovatus (G. Gaertn., } \\
\text { B. Mey. \& Scherb.) Willd. }\end{array}$ & $\begin{array}{l}\text { Brachypodium sylvaticum } \\
\text { (Huds.) PB. }\end{array}$ & Rubus fruticosus agg. \\
\hline Herb biomass $\left[\mathrm{t} \mathrm{C} \mathrm{ha}{ }^{-1}\right]$ & $0.32 \pm 0.08$ & $1.16 \pm 0.45$ & $2.26 \pm 0.65$ \\
\hline \multicolumn{4}{|l|}{ Fine roots } \\
\hline $\begin{array}{l}\text { Fine roots }(0-10 \mathrm{~cm}) \\
{\left[\mathrm{t} \mathrm{C} \mathrm{ha}^{-1}\right]}\end{array}$ & $1.56 \pm 0.68$ & $0.40 \pm 0.50$ & $0.79 \pm 0.34$ \\
\hline \multicolumn{4}{|l|}{ Soil characteristics } \\
\hline $\begin{array}{l}\text { Soil organic layer } \\
\text { (LF) thickness }[\mathrm{cm}]\end{array}$ & $0.5-2$ & $3-4$ & $0.5-2$ \\
\hline $\begin{array}{l}\text { Soil mineral horizon } \\
\text { (A) thickness [cm] }\end{array}$ & $5.5-22$ & $6-12$ & $7-20$ \\
\hline $\mathrm{C}_{\mathrm{org}} \mathrm{A}(0-10 \mathrm{~cm})\left[\mathrm{g} \mathrm{kg}^{-1}\right]$ & $94.4 \pm 26.7$ & $119.5 \pm 35.8$ & $131.7 \pm 41.0$ \\
\hline
\end{tabular}

Herb biomass was harvested at six random locations within each section (mean \pm SD). Fine root biomass was determined by 12 soil cores $(0-$ $10 \mathrm{~cm}$ soil depth) per section (mean $\pm \mathrm{SD}$ ). Soil organic C contents of the A-horzion were estimated by additional 12 soil cores (mean $\pm \mathrm{SD}$ ). Soil layer thickness was assessed at five random locations within each stand section

$\left.\left[\mathrm{t} \mathrm{C} \mathrm{ha}{ }^{-1} \mathrm{yr}^{-1}\right]\right)$ and the estimated autotrophic soil $\mathrm{CO}_{2}$ efflux $(a[\%])$ from PD06:

$P D 03 a=\frac{P D 06 a}{P D 06 f} \times P D 03 f$

Litter and ground vegetation biomass sampling

Five litter collectors ( $0.68 \mathrm{~m}$ diameter) were placed in MS in November 2013. Litter collectors were emptied in March and November 2014. The litter was oven-dried at $105{ }^{\circ} \mathrm{C}$ and weighed. The $\mathrm{C}$ content of litter was assumed as $50 \%$ of the dry weight (De Wit et al. 2006).

To derive an estimate of litter input from ground vegetation, ground vegetation was harvested at the end of the vegetation period in September 2014 from all sites. On each site, six random plots were selected. The above ground vegetation was clipped inside a wooden frame $(0.5 \times 0.5 \mathrm{~m})$, oven-dried at $105^{\circ} \mathrm{C}$ and weighed. The $\mathrm{C}$ content of biomass was assumed as $47.5 \%$ of the dry weight (Schlesinger 1991). We assumed that the harvested ground vegetation biomass roughly resembled the annual (above) ground vegetation litter input.

Fine root biomass, soil $\mathrm{C}$ and $\mathrm{N}$ and microbial biomass

At each of the 12 plots per section, a soil core $(7 \mathrm{~cm}$ diameter) for fine root analyses was taken in the vicinity of the $\mathrm{CO}_{2}$ collar, in June 2014. Coring depth was $10 \mathrm{~cm}$, as most of the fine roots were considered in the upper soil layer (> $80 \%$ of total fine root biomass was found at $0-10 \mathrm{~cm}$ soil depth at both the disturbed and undisturbed study locations; Kobler unpublished data). Fine roots were washed to remove all soil particles. Root fragments were picked out of the samples with tweezers, sorted into living and dead, and further ordered by diameter and origin (grass roots, tree roots). The roots 
were considered as living when the stele was bright and resilient (Vogt and Persson 1991). Roots less than $2 \mathrm{~mm}$ in diameter were classified as fine roots. After sorting, fine roots were oven-dried at $105{ }^{\circ} \mathrm{C}$. The $\mathrm{C}$ content of roots was considered to be $50 \%$ of the dry weight (De Wit et al. 2006).

A second soil core per plot was taken to assess organic $\mathrm{C}$ and $\mathrm{N}$ contents of the upper $10 \mathrm{~cm}$ mineral soil. Total $\mathrm{C}$ and $\mathrm{N}$ contents of the soil horizons were determined with a LECO CN-2000 dry combustion analyzer (LECO Corporation, MI, USA). Organic C content was assessed by correcting total soil $\mathrm{C}$ by carbonate contents (ISO 10694; www.iso.ch). Microbial biomass $\mathrm{C}$ and $\mathrm{N}$ were determined using a modified version of the chloroform fumigation extraction (CFE) method (Schinner et al. 1996). $10 \mathrm{~g}$ of homogenized soil were weighed into $100 \mathrm{ml}$ Erlenmeyer flasks to be chloroform fumigated and $5 \mathrm{~g}$ were weighed into plastic beakers as control samples. The soil samples in the Erlenmeyer flasks were kept inside a desiccator with sodium lime and wet filter papers within a chloroform atmosphere for $24 \mathrm{~h}$ at $25^{\circ} \mathrm{C}$. After fumigation the samples were split into two $5 \mathrm{~g}$ samples. $25 \mathrm{ml}$ of $2 \mathrm{M}$ $\mathrm{KCl}$ solution were added to the samples that were then shaken for $30 \mathrm{~min}$ and afterwards filtered through $\mathrm{N}$-free filters. Control samples were processed using the same procedure. The $\mathrm{C}$ and $\mathrm{N}$ content of the $\mathrm{KCl}$ extracts were measured with a TOC-V CPH E200V soluble analyzer linked with a TN-unit TNM-1220 V (Shimadzu, Kyoto, Japan). For calibration a dilution series of a standard stock solution was added. Microbial biomass $\mathrm{C}$ and $\mathrm{N}$ contents in $\mu \mathrm{g} \mathrm{g}^{-1}$ dry matter were calculated by subtracting the $\mathrm{C}$ and $\mathrm{N}$ contents of the control sample from the mean $\mathrm{C}$ and $\mathrm{N}$ contents of the two fumigated samples.

\section{C budgeting}

In a first step, we used an exponential model (Eq. 2) between soil temperature and soil respiration to estimate the annual soil $\mathrm{CO}_{2}$ efflux of each individual plot (Janssens et al. 2003).

$$
R_{S}=F_{10} Q_{10}\left(\frac{T-10}{10}\right)
$$

$R_{s}$ was the soil $\mathrm{CO}_{2}$ efflux rate $\left(\mu \mathrm{mol} \mathrm{CO} \mathrm{CO}^{-2} \mathrm{~s}^{-1}\right)$, $T$ the soil temperature $\left({ }^{\circ} \mathrm{C}\right)$ at a soil depth of $5 \mathrm{~cm}, F_{10}$ the soil $\mathrm{CO}_{2}$ efflux at a soil temperature of $10{ }^{\circ} \mathrm{C}$ and $Q_{10}$ denoted the factor by which $\mathrm{R}_{\mathrm{s}}$ increases when the soil temperature is rising by $10^{\circ} \mathrm{C}$. Nonlinear modelling was performed by means of the $\mathrm{R}$ package "minpack.lm" (Elzhov et al. 2013).

Equation (2) was parameterized for each individual plot including the clipping plots, as well as for the trenching and control plots, using the observed $\mathrm{R}_{\mathrm{s}}$ in combination with the manually measured soil temperature at a depth of $5 \mathrm{~cm}$. Subsequently, daily and annual plot specific cumulative $R_{s}$ were calculated from the models using the high temporal resolution soil temperature data.

The basal area, mean tree height, and stem volume of the mature stand were determined by angle-count sampling (5 angle-count samples per stand) (Bitterlich 1984). We used a detailed assessment of biomass stocks and increment of the stem, branch and coarse root compartments of a comparable adjacent stand with similar tree species composition, tree age, and management history (Kobler et al. 2015) to deduce the standing biomass and biomass increment of the mature stand. Biomass stocks and increment of the mature stand were adjusted by the observed difference in stem volume between the two neighbouring stands. Net ecosystem productivity (NEP) was calculated as:

$\mathrm{NEP}=$ annual biomass increment + annual litter fall - annual $\mathrm{R}_{\mathrm{h}}$

For the two clearing sites (PD06, PD03), we assumed that the entire aboveground biomass stock of the ground vegetation annually enters the soil as litter. Therefore, the NEP was calculated as litter input minus $\mathrm{R}_{\mathrm{h}}$. Turnover rate for fine roots was considered as $0.8 \mathrm{yr}^{-1}$ (Gill and Jackson 2000) for trees and ground vegetation.

\section{Statistical analysis}

Effects of time since disturbance on soil $\mathrm{CO}_{2}$ efflux, soil temperature, and soil moisture were assessed by means of repeated measures ANOVA and post hoc pairwise student $\mathrm{t}$ tests with Bonferroni $p$-value adjustment. Effects of time since disturbance on accumulated $\mathrm{R}_{\mathrm{s}}$, soil $\mathrm{C}$ and $\mathrm{N}$ contents, ground vegetation biomass, fine root biomass and microbial biomass were analysed by means of one-way ANOVA. In the case of significant effects $(p<0.05)$, post-hoc comparisons were made using Tukey's honest significant difference (HSD) test. We used square root or logarithmic transformations to meet the assumptions of 
normality and homogeneity of variance. We used Pearson's correlation coefficient to analyse the relationship between the annual $\mathrm{R}_{\mathrm{s}}$ and the microbial biomass respectively the soil organic $\mathrm{C}$ as well as the relationship between fine root biomass and soil organic $\mathrm{C}$ and N. All statistics were carried out with R (R Core Team 2015) at a significance level of $95 \%$.

\section{Results}

Soil temperature, moisture and respiration $\left(\mathrm{R}_{\mathrm{s}}\right)$

Average soil temperatures during $\mathrm{R}_{\mathrm{s}}$ measurements were $9.6 \pm 0.3{ }^{\circ} \mathrm{C}(\mathrm{MS}), 10.1 \pm 0.4{ }^{\circ} \mathrm{C}$ (PD06) and $10.6 \pm 0.4{ }^{\circ} \mathrm{C}$ (PD03). Mean annual (continuously measured) soil temperatures were $8.2 \pm 0.2^{\circ} \mathrm{C}$ (MS), $8.0 \pm 0.3{ }^{\circ} \mathrm{C}$ (PD06) and $8.5 \pm 0.3{ }^{\circ} \mathrm{C}$ (PD03). Differences between mean annual soil temperatures as well as soil temperatures during $\mathrm{R}_{\mathrm{s}}$ measurements did not differ significantly between MS and the clearcut areas. Mean soil moisture was $39.5 \pm 0.7 \%$ (MS), $49.2 \pm 0.9 \%$ (PD06) and $52.3 \pm 0.9 \%$ (PD03). Mean soil moisture contents differed significantly between the forest sections $(p=0.028)$. Post hoc test showed that soil moisture was different between all three sections $(p<0.022)$.

$\mathrm{R}_{\mathrm{s}}$ exhibited a clear seasonal pattern following changes in soil temperature, with the peak respiration rates recorded during summer (Fig. 1a). Mean measured $\mathrm{R}_{\mathrm{s}}$ over the study period was $2.60 \pm 0.13 \mu \mathrm{mol}$ $\mathrm{CO}_{2} \mathrm{~m}^{-2} \mathrm{~s}^{-1}$ (MS), $2.73 \pm 0.14 \mu \mathrm{mol} \mathrm{CO} \mathrm{CO}^{-2} \mathrm{~s}^{-1}$ (PD06) and $2.45 \pm 0.13 \mu \mathrm{mol} \mathrm{CO} \mathrm{m}^{-2} \mathrm{~s}^{-1}$ (PD03). Mean measured $\mathrm{R}_{\mathrm{s}}$ did not differ significantly between stand sections. The temperature driven $R_{s}$ model (Eq. 2) explained between 79 and $86 \%$ of the temporal variation in measured $R_{s}$. The model slightly overestimated $R_{S}$ at lower $R_{s}$ rates and slightly overestimated $R_{S}$ at higher $R_{s}$ rates (Fig. A2). The modelled annual $\mathrm{R}_{\mathrm{S}}$ was $8.88 \pm 0.28 \mathrm{t} \mathrm{C} \mathrm{ha}^{-1}$ (MS), $8.85 \pm 0.28 \mathrm{t} \mathrm{C} \mathrm{ha}^{-1}$ (PD06) and $8.53 \pm 0.24 \mathrm{t} \mathrm{C} \mathrm{ha}^{-1}$ (PD03) and did not differ significantly between stand sections.

$\mathrm{R}_{\mathrm{s}}$ of trenched plots on MS was on average $44 \pm 3 \%$ lower than at the corresponding control plots (Fig. 2, Table 2). Average soil moisture was $15 \pm 1$ Vol\% higher at trenched plots $(p<0.001)$ than at control plots (average moisture: $35 \pm 1$ Vol\%). Mean soil temperatures were $9.5 \pm 1.1^{\circ} \mathrm{C}$ (trenched) and $9.5 \pm 1.0{ }^{\circ} \mathrm{C}$ (control).

There was no clear effect on $\mathrm{R}_{\mathrm{s}}$ during the initial phase of clipping. After a gradual decrease, clipped plots stabilized in autumn 2014 at $\mathrm{R}_{\mathrm{s}}$ rates $\sim 35 \%$ lower than at untreated plots (Fig. 3, Table 2). Soil moisture and temperature did not differ significantly between the clipped and untreated plots.

Litterfall and ground vegetation biomass

Aboveground tree litterfall was $1.80 \mathrm{t} \mathrm{C} \mathrm{ha}^{-1} \mathrm{yr}^{-1}$ and ground vegetation biomass was $0.32 \pm 0.08 \mathrm{t} \mathrm{C} \mathrm{ha}^{-1}$ at MS (Tables 1 and 2). Harvested ground vegetation biomass amounted to $2.26 \pm 0.65 \mathrm{t} \mathrm{C} \mathrm{ha}^{-1} \mathrm{yr}^{-1}$ at PD06, and $1.16 \pm 0.45 \mathrm{t} \mathrm{C} \mathrm{ha}^{-1} \mathrm{yr}^{-1}$ at PD03. Differences in harvested ground vegetation biomass were statistically significant between all stand sections $(p<0.006)$.

Soil properties, $\mathrm{C}$ and $\mathrm{N}$ contents, fine root and microbial biomass

Soil organic layer thickness varied between 0.5 and $2 \mathrm{~cm}$ at MS and PD06, and between 3 and $4 \mathrm{~cm}$ at the recent clear-cut section PD03. Mineral A-horizon thickness showed high spatial heterogeneity and ranged from 5.5-22 cm (Table 1). Soil organic C contents ranged between $94 \pm 8 \mathrm{~g} \mathrm{~kg}^{-1} \mathrm{DW}$ (MS) and $131 \pm 11 \mathrm{~g} \mathrm{~kg}^{-1}$ DW (PD06) (Table 1). Soil C $(p=0.048)$ and $\mathrm{N}$ $(p=0.014)$ contents were significantly lower at MS when compared to PD06.

Living fine root biomass was highest at MS $\left(1.56 \pm 0.68 \mathrm{t} \mathrm{C} \mathrm{ha}^{-1}\right)$. The clearings showed significantly lower $(p<0.002)$ fine root biomass, but PD06 $\left(0.79 \pm 0.34 \mathrm{t} \mathrm{C} \mathrm{ha}^{-1}\right)$ showed nearly twice the amount of fine root biomass as PD03 $\left(0.40 \pm 0.50 \mathrm{t} \mathrm{C} \mathrm{ha}^{-1}\right.$, Table 1), thereby almost exactly making up the difference in aboveground biomass of PD06 and PD03 (Table 1). All living fine roots at the clearings were of ground vegetation origin, whereas tree fine roots represented $\sim 90 \%$ at MS.

Microbial biomass $\mathrm{C}$ amounted to $0.76 \pm 0.26 \mathrm{mg} \mathrm{g}^{-1}$ $\mathrm{DM}$ (MS), $0.61 \pm 0.40 \mathrm{mg} \mathrm{g}^{-1} \mathrm{DM}$ (PD03) and $0.60 \pm 0.18 \mathrm{mg} \mathrm{g}^{-1} \mathrm{DM}$ (PD06). Due to the high spatial heterogeneity the differences were not statistically significant. The cumulative annual $R_{s}$ of the individual stages/stand-sections neither correlated significantly 
Fig. 1 a Soil $\mathrm{CO}_{2}$ efflux of the different stand sections (mean $\pm \mathrm{SE}, n=12$ ). b Manually measured and high resolution soil temperature and soil moisture of the mature stand (MS).

Deviations of soil temperature (c) and moisture (d) from that of the mature stand (MS = dashed zero line). Open squares represent the more recently disturbed stand section (PD03, 2011 clearing) and open triangles represent the less recently disturbed stand section (PD06, 2008 clearing)

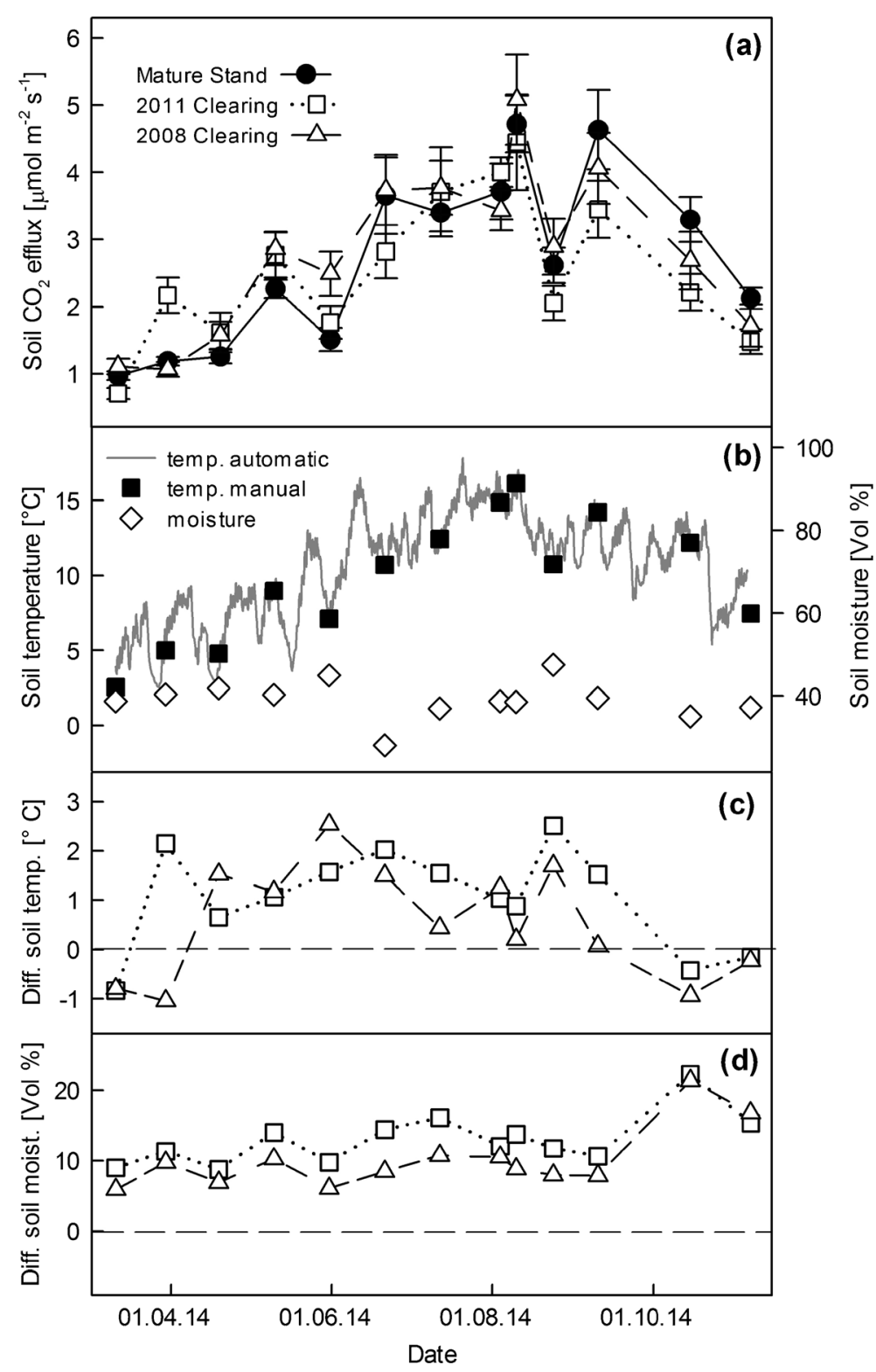

with microbial biomass $\mathrm{C}$, soil organic $\mathrm{C}$ and $\mathrm{N}$ contents, nor with fine root biomass.

\section{C budgeting}

Estimated NEP and its components are presented in (Table 2). MS was a $\mathrm{C}$ sink to the atmosphere, while PD06 and PD03 were C sources. The estimated C loss from PD03 was nearly twice as high as the estimated C loss from the densely vegetated PD06.

\section{Discussion}

As hypothesized, the two disturbed sites were $\mathrm{C}$ sources while the mature forest stand was a $\mathrm{C}$ sink to the atmosphere. Although there was no tree regeneration, the $\mathrm{C}$ source strength of the clear-cut sites decreased significantly with time since disturbance. The $\mathrm{C}$ loss six years after clear-cutting was almost 50\% lower than three years after clear-cutting. As hypothesized, lower heterotrophic soil respiration rates together with the high $\mathrm{C}$ input from the dense grassy ground vegetation 


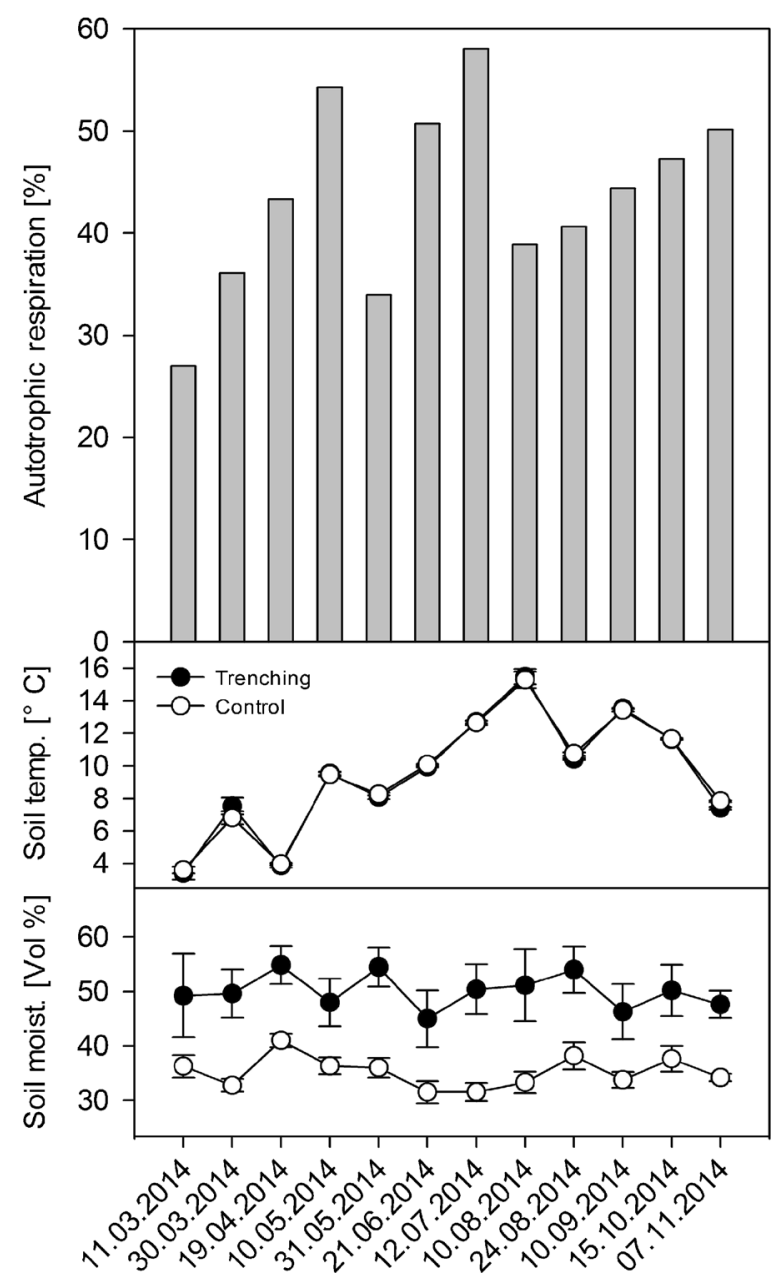

Fig. 2 Trenching experiment at the mature stand. The upper panel shows the autotrophic contribution to $\mathrm{R}_{\mathrm{s}}$. The middle and lower panels show soil temperature (mean $\pm \mathrm{SE}, n=12$ ) and soil moisture (mean $\pm \mathrm{SE}, n=12$ ) from the trenched and associated control plots

decreased the ecosystem $\mathrm{C}$ loss with time since disturbance.

The estimated NEPs of our study are in the range of values from Kowalski et al. (2004), reporting forest stands as $\mathrm{C}$ sinks ranging from ca. 1.00 to $5.00 \mathrm{t} \mathrm{C}$ $\mathrm{ha}^{-1} \mathrm{yr}^{-1}$ and cleared sites as $\mathrm{C}$ sources of similar magnitude. Likewise, other studies report considerable $\mathrm{C}$ loss to the atmosphere shortly after disturbance (Knohl et al. 2002; Brown et al. 2010; Amiro et al. 2010; Edburg et al. 2012; Mathys et al. 2013). Many of these studies focused on the first 1-3 years after disturbance or on even shorter timescales during which the disturbed sites generally are strong $\mathrm{C}$ sources. In most longer-term studies, clearings were re-planted or regenerated naturally within a comparatively short timeframe (Kowalski et al. 2004; Humphreys et al. 2005; Takagi et al. 2009; Amiro et al. 2010; Williams et al. 2014). There are thus only a few studies which specifically address the $\mathrm{C}$ dynamics of clearings with slow or failed tree regeneration due to heavy competition from ground vegetation. Kolari et al. (2004), for instance, found that the NEP of a 4 year old Scots pine clearing without any tree regeneration was $-2.6 \mathrm{t} \mathrm{C}$ $\mathrm{ha}^{-1} \mathrm{yr}^{-1}$, which is close to the NEP estimate of the six years old clearing (PD06) in our study $(-2.9$ t C $\left.\mathrm{ha}^{-1} \mathrm{yr}^{-1}\right)$. Studying the effects of large-scale windthrow in a similar forest ecosystem as studied here, Mayer et al. (2014, 2017) found that windthrow substantially increased soil temperatures at south facing slopes, facilitating SOM decomposition, $R_{s}$, and $R_{h}$. As a result, windthrown areas suffered a significant loss of soil $\mathrm{C}$ throughout the first six years after disturbance (Mayer et al. 2017). In contrast to our site, ground vegetation cover remained scarce even after 6 years post windthrow, and the contribution of $\mathrm{R}_{\mathrm{a}}$ remained low ( $<$ $20 \%$ ). Conversely, higher $\mathrm{R}_{\mathrm{s}}$ rates than in our study (11 $\mathrm{t}$ $\mathrm{C} \mathrm{ha}^{-1} \mathrm{yr}^{-1}$ ) were reported for another windthrow area 12 years after disturbance (Mayer et al. 2014). At this site, ground vegetation was comparable in density to our PD06 site. However, autotrophic and heterotrophic sources were not distinguished and the net $\mathrm{C}$ loss from this site thus remains unresolved.

Effects of forest disturbance on $\mathrm{R}_{\mathrm{s}}$ are diverse. On the one hand, disturbance decreases or even ceases $R_{a}$ and thereby reduces $\mathrm{R}_{\mathrm{s}}$ (Zerva and Mencuccini 2005; Edburg et al. 2011; Moore et al. 2013). On the other hand, disturbance can favor the soil microclimate (i.e. increase soil temperature and/or moisture) for SOM decomposition, and additional above and below ground litter becomes available for decomposers. Therefore, post-disturbance $\mathrm{R}_{\mathrm{s}}$ was frequently observed to attain levels equivalent to undisturbed forest stands (Kolari et al. 2004; Morehouse et al. 2008; Forrester et al. 2013; Mayer et al. 2014, 2017). A key factor influencing $\mathrm{R}_{\mathrm{s}}$ is soil temperature. In contrast to our hypothesis, disturbance had only a minor effect on soil temperature at our site. At both clearings soil temperature was slightly elevated during most of the growing season (Fig. 1c), but the mean annual soil temperatures across the different stand-sections were similar. The reason was that soils at the clearings remained cooler during spring, as snow cover disappeared several weeks later compared to the stand with closed canopy (Fig. A3). The positive 
Table 2 Carbon fluxes and net ecosystem productivity (NEP) during 2014

\begin{tabular}{|c|c|c|c|c|c|c|c|}
\hline \multicolumn{2}{|l|}{ Stage/stand-section } & \multicolumn{2}{|c|}{ Mature stand (MS) } & \multicolumn{2}{|c|}{2011 clearing (PD03) } & \multicolumn{2}{|c|}{2008 clearing (PD06) } \\
\hline Annual biomass increment & {$\left[\mathrm{tC} \mathrm{ha}^{-1} \mathrm{yr}^{-1}\right]$} & 3.8 & & & & & \\
\hline Soil respiration (Rs) & {$\left[\mathrm{t} \mathrm{C} \mathrm{ha}^{-1} \mathrm{yr}^{-1}\right]$} & 8.9 & \pm 0.3 & 8.5 & \pm 0.2 & 8.9 & \pm 0.3 \\
\hline \multirow[t]{2}{*}{ Autotrophic } & {$[\%]$} & 44 & & 18 & & 35 & \\
\hline & {$\left[\mathrm{t} \mathrm{C} \mathrm{ha}^{-1} \mathrm{yr}^{-1}\right]$} & 3.9 & & 1.5 & & 3.1 & \\
\hline \multirow[t]{2}{*}{ Heterotrophic } & {$[\%]$} & 56 & & 82 & & 65 & \\
\hline & {$\left[\mathrm{t} \mathrm{C} \mathrm{ha}^{-1} \mathrm{yr}^{-1}\right]$} & 5.0 & & 7.0 & & 5.8 & \\
\hline Tree litter & {$\left[\mathrm{t} \mathrm{C} \mathrm{ha}^{-1} \mathrm{yr}^{-1}\right]$} & 1.8 & & & & & \\
\hline Herb litter & {$\left[\mathrm{t} \mathrm{C} \mathrm{ha}^{-1} \mathrm{yr}^{-1}\right]$} & 0.3 & \pm 0.1 & 1.2 & \pm 0.5 & 2.3 & \pm 0.7 \\
\hline Root litter & {$\left[\mathrm{tC} \mathrm{ha}{ }^{-1} \mathrm{yr}^{-1}\right]$} & 1.2 & \pm 0.5 & 0.3 & \pm 0.4 & 0.6 & \pm 0.3 \\
\hline NEP & {$\left[\mathrm{t} \mathrm{C} \mathrm{ha}^{-1} \mathrm{yr}^{-1}\right]$} & 2.1 & & -5.5 & & -2.9 & \\
\hline
\end{tabular}

Annual biomass increment represents the estimated total tree biomass increment of MS (mean \pm SD). All herbal biomass (increment) was assumed to annually enter the soil (herb biomass $=$ herb litter). Annual soil respiration was modelled for each plot individually (mean $\pm \mathrm{SD}$ ). Autotrophic and heterotrophic components were estimated by means of trenching (MS) and clipping (clearings) and annual sums were modelled for each plot and component, respectively. Tree litterfall represents a bulk sample of 5 collectors. Fine root litterfall was estimated from fine root biomass $\left(0-10 \mathrm{~cm}\right.$ depth) with a turnover rate of $0.8 \mathrm{yr}^{-1}$ (mean $\pm \mathrm{SD}$ )

influence of direct sunlight on soil temperature was limited by the NW exposition and the flat terrain of our site, e.g. compared to the $\mathrm{S}$ exposed slopes studied by Mayer et al. (2014, 2017). In our study, parts of the clearings had been affected by shading of the neighbouring mature trees, especially during seasons with lower solar altitude. Shading had been found to significantly affect soil temperature and Rs in forest gaps (Schatz et al. 2012). The comparably small size (0.5-1 ha) of the investigated clearings could therefore be a further reason that only minor changes in soil temperature were observed. In contrast to soil temperature, soil moisture was significantly higher in the clearings. This is a frequently observed pattern, attributable to the lack of water uptake and evapotranspiration by trees (Palviainen et al. 2004). The higher water availability likely had only minor effects on $\mathrm{R}_{\mathrm{s}}$ because soil moisture never became a limiting factor to decomposer microbes at any disturbed or undisturbed stand section (Fig. 1b).

If temperature and moisture effects on $\mathrm{R}_{\mathrm{s}}$ were minor, then other factors must have attained $R_{s}$ at the two clearings. The organic layer, which mainly consisted of decomposing needles and twig compartments, was significantly thicker at the recent clearing (PD03) (Table 1). This indicates that easily decomposable organic material from tree residues was still readily available to decomposers at PD03, and that its decomposition contributed to the soil $\mathrm{CO}_{2}$ efflux. The same likely holds true for below ground fluxes, where dead roots of the recently killed trees were still available for decomposition. Lower absolute $\mathrm{R}_{\mathrm{h}}$ at PD06 (Table 2) also points towards a decline in readily available labile SOM/litter over time since disturbance.

A significant contribution of $\mathrm{R}_{\mathrm{s}}$ was autotrophic at PD06, i.e., the site which was covered by dense predominantly grassy ground vegetation. Our estimated $35 \%$ contribution of $\mathrm{R}_{\mathrm{a}}$ is in line with results from other clipping experiments in grasslands (20-50\%) (Kuzyakov and Cheng 2001; Wan and Luo 2003; Bahn et al. 2006), and with that of a trenching experiment at a clear-cut site in Harvard forest (34\%) (Williams et al. 2014). We repeatedly clipped with the intention to kill the grassy ground vegetation and to offset root respiration. However, even after a whole growing season of repeated clipping, grasses were still alive and resprouted in-between consecutive $R_{s}$ measurements. Therefore, root respiration still contributed to $\mathrm{R}_{\mathrm{s}}$ at our clipping plots. The $35 \% \mathrm{R}_{\mathrm{a}}$ is thus a conservative estimate, and the real autotrophic contribution at PD06 was likely higher (and the soil C losses to the atmosphere correspondingly lower). Annual estimated $\mathrm{R}_{\mathrm{s}}$ from MS falls within values from other temperate forests (e.g. Knohl et al. 2008; Schindlbacher et al. 2014; Mayer et al. 2014). The contribution of $R_{a}$ to $R_{s}$ (44\%) was within values of comparable mature forest ecosystems as well (Hanson et al. 2000; Zerva and Mencuccini 2005; Subke et al. 2006).

Similar to the clipping method, trenching holds uncertainties. Trenched plots, for instance, had slightly 


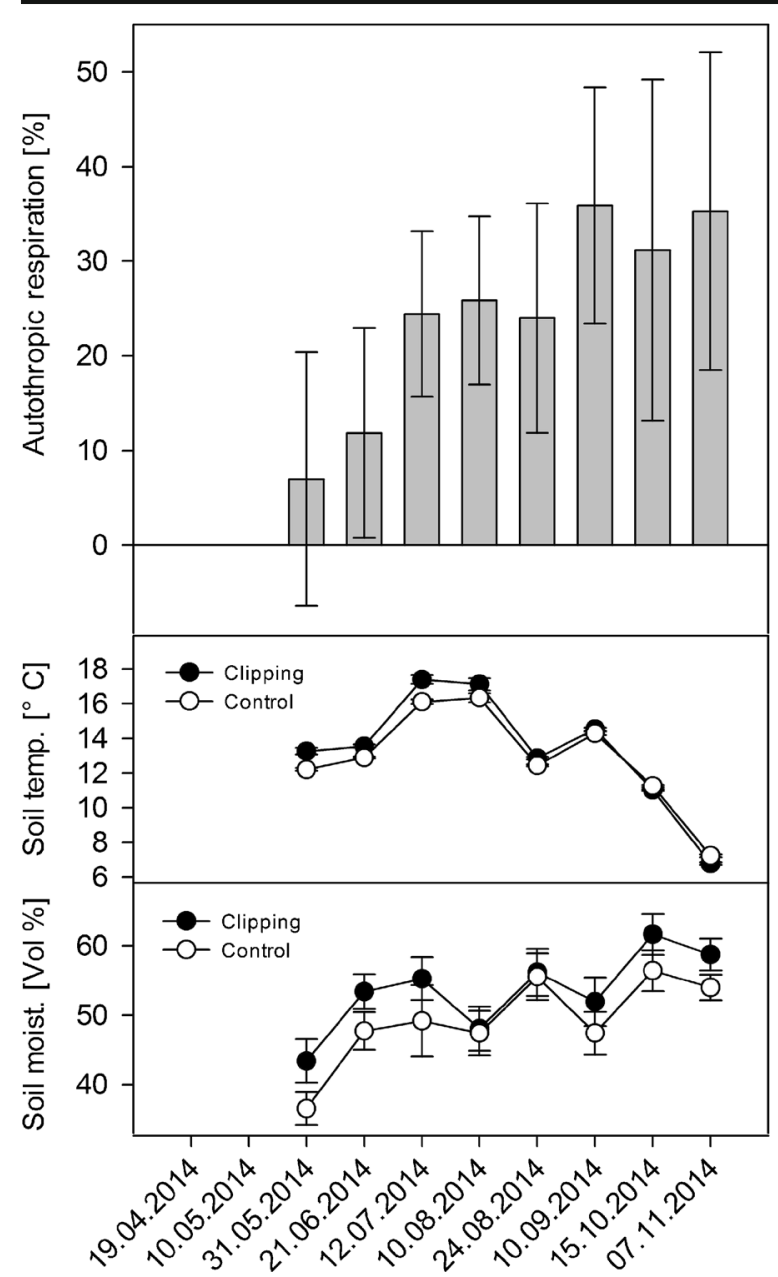

Fig. 3 Clipping experiment. The upper panel shows the autotrophic contribution to $\mathrm{R}_{\mathrm{s}}$ (mean $\pm \mathrm{SE}, n=12$ ). The mid and lower panel show soil temperature (mean $\pm \mathrm{SE}, n=12$ ) and soil moisture (mean $\pm \mathrm{SE}, n=12$ ) from the clipping and associated control plots

higher soil moisture contents as control plots. Differences in soil moisture can cause methodological bias if control plots dry out during certain drought periods, or if SOM decomposition becomes unfavorable when trenched plots are fully water saturated (Díaz-Pinés et al. 2010). In our study, moisture-induced bias was unlikely because soil moisture content in control and trenched plots never became limiting or oversaturated (Fig. 2). Further uncertainty arises from decomposition of dead roots in trenching plots, which can add to the soil $\mathrm{CO}_{2}$ efflux. Since the trenching plots were already established 5 years prior to our study (Kobler et al. 2015), most dead fine roots should, however, have been decomposed by the time our measurements took place. Nonetheless, due to the number of caveats, trenching provides only a rough proxy of autotrophic and heterotrophic contributions to overall respiration. $\mathrm{R}_{\mathrm{h}}$ is the major $\mathrm{C}$ outflux of the ecosystem, and uncertainty in its contribution will have considerable impacts on the $\mathrm{C}$ budget. $A>80 \%$ heterotrophic contribution to $R_{S}$ would turn MS to a $\mathrm{C}$ source. Such a huge deviation of our estimate (66\%), however, is far beyond the expected uncertainty related to the trenching method.

A further pathway of C loss is leaching of dissolved organic carbon (DOC) or dissolved inorganic carbon (DIC) of biogenic origin (Kindler et al. 2011; Schindlbacher et al. 2015). In our study, we did not assess $\mathrm{C}$ leaching. The magnitude of $\mathrm{C}$ loss via leaching is several times lower than that via $\mathrm{R}_{\mathrm{h}}$. Schindlbacher et al. (2009), for instance, estimated DOC leaching of $1.5-3 \mathrm{~g} \mathrm{~m}^{-2} \mathrm{yr}^{-1}$ for a mature spruce stand at a similar site, which falls well within the range of values for other temperate forests in Europe (Kindler et al. 2011). It is likely that PD03 and PD06 showed higher C leaching when compared to MS, as overall seepage likely was higher on the cleared sites (Neff and Asner 2001). However, due to the minor contribution of $\mathrm{C}$ leaching to the overall soil $\mathrm{C}$ loss, potential clearing effects on $\mathrm{C}$ leaching can be expected to add only insignificantly to our NEP estimates.

To come up with a realistic soil $\mathrm{C}$ budget, it is not only important to assess the $\mathrm{C}$ loss but also the $\mathrm{C}$ input to the system. Annual above-ground tree litter estimates were robust and fall within values from other temperate mountainous forests (Perruchoud et al. 1999; Caprez et al. 2012). The dense grassy ground vegetation at the six years old clearing (PD06) was dominated by Calamagrostis epigejos and other graminoids (Table 1). These communities are common and widely distributed in Central European forests, especially where the natural regeneration of trees is limited (Máliš et al. 2013). Above-ground living biomass at PD06 was $2.3 \mathrm{t}$ $\mathrm{C} \mathrm{ha}^{-1}$, which is in the range of similar plant communities reported elsewhere (1.5 $\mathrm{t} \mathrm{C} \mathrm{ha}^{-1}$ (Pysek 1991), $3.1 \mathrm{t}$ $\mathrm{C}^{-1}{ }^{-1}$ (Máliš et al. 2013)). At PD03, ground vegetation biomass was lower $\left(1.2 \mathrm{t} \mathrm{Cha}^{-1}\right)$, which shows that the improved light availability promotes a rapid spread of herbaceous plants and grasses in cleared areas (Ammer 1996; Palviainen et al. 2005; Donoso and Nyland 2006; Naaf and Wulf 2007; Kern et al. 2012; Kramer et al. 2014; Pröll et al. 2015). In our study, we used the above ground biomass as a proxy for the annual above ground litter input. The true above ground litter input might have been higher, as the ground vegetation biomass 
was sampled in September, and further biomass growth thereafter is likely. Moreover, potential above ground litter input prior to biomass harvesting was not accounted for.

Our tree fine root biomass estimates $\left(1.6 \mathrm{t} \mathrm{C} \mathrm{ha}^{-1}\right)$ are within the range of those observed for similar Norway spruce forests (Helmisaari et al. 2007; Brunner et al. 2013). The fine root biomass from the dense ground vegetation at PD06 $\left(0.8 \mathrm{t} \mathrm{C} \mathrm{ha}^{-1}\right)$ falls within fine root biomass estimates at grassland sites (Solly et al. 2013). The turnover rate $\left(0.8 \mathrm{yr}^{-1}\right)$ used to calculate the below ground $\mathrm{C}$ input via fine roots is within the average of reported values (Finér et al. 2011; Brunner et al. 2012). It, however, needs to be noted that only the top $10 \mathrm{~cm}$ of the soil were sampled and analyzed for fine root biomass in our study. Although most Norway spruce fine roots are typically located in the top-soil (Ostonen et al. 2005), a fraction of fine roots is likely present also in soil layers deeper than $10 \mathrm{~cm}$. Accordingly, our estimate for tree fine root biomass and corresponding litter input at MS is a conservative estimate. At the two forest clearings, the $10 \mathrm{~cm}$ root coring should have reached most of the rooting zone of the ground vegetation species (Ostonen et al. 2005; Wu et al. 2011). The biomass increment estimate of MS is likely to be robust, as it was derived from a detailed assessment of a close-by stand (200 $\mathrm{m}$ away) of the same age, stand and site properties (Kobler et al. 2015).

Notwithstanding all limitations and uncertainties, we are confident that the applied methods were adequate to answer our prime question, how non-woody ground vegetation growth affected the $\mathrm{C}$ balance of poorly regenerating forest clearings. To avoid overinterpreting the effects of ground vegetation on $\mathrm{C}$ cycling, we kept our estimates of ground vegetation, autotrophic soil respiration, litter input and fine root turnover conservative (see above). Therefore, the estimated $\mathrm{C}$ losses from forest clearings presented here are an upper bound of the potential C loss. Spatial replication among various disturbance sites/chronosequences could further illustrate whether the results of our case study apply at larger spatial scales.

Our results indicate that fast growing grassy ground vegetation can mitigate parts of the ecosystem C loss after disturbance. However, from a forest management and climate change mitigation perspective, un-stocked sites such as the ones studied here, remain largely undesirable. Once established, dense grassy ground vegetation strongly inhibits tree regeneration (Pröll et al.
2015). Consequently, tree planting and tending often remains the only pathway towards successfully establishing the next generation of trees under these conditions. Such measures are labour intensive and costly, and could be avoided by reducing inhibiting factors such as browsing pressure, before a dense grass cover takes over. On the other hand, patchy and open habitats have considerable value for biodiversity, as they provide habitat for a wide range of species groups (Swanson et al. 2011; Thom et al. 2017).

\section{Conclusions}

Here we show that disturbed areas in a central European mountain forest initially lose high amounts of $\mathrm{C}$ to the atmosphere. Our analyses highlights that while tree regeneration is slow or absent, the establishment of a cover of fast-growing non-woody ground vegetation, together with decreasing heterotrophic soil respiration, can reduce the ecosystem $\mathrm{C}$ loss in the first years after disturbance. Although largely undesirable from a forest management perspective, slowly regenerating forest clearings loose less $\mathrm{C}$ than suggested from short term studies extrapolating fluxes from the initial years after disturbance, and ignoring the role of ground vegetation in the forest $\mathrm{C}$ cycle.

Acknowledgements Open access funding provided by Austrian Science Fund (FWF). The study was funded by the Austrian Science Fund FWF (project P 25503). We thank Lisa-Maria Bauer for her help with fine roots. We thank two anonymous reviewers for helpful comments on an earlier version of the manuscript.

Open Access This article is distributed under the terms of the Creative Commons Attribution 4.0 International License (http:// creativecommons.org/licenses/by/4.0/), which permits unrestricted use, distribution, and reproduction in any medium, provided you give appropriate credit to the original author(s) and the source, provide a link to the Creative Commons license, and indicate if changes were made.

\section{References}

Amiro BD, Barr AG, Barr JG et al (2010) Ecosystem carbon dioxide fluxes after disturbance in forests of North America. J Geophys Res 115:G00K02

Ammer C (1996) Impact of ungulates on structure and dynamics of natural regeneration of mixed mountain forests in the Bavarian Alps. For Ecol Manag 88:43-53 
Bahn M, Knapp M, Garajova Z et al (2006) Root respiration in temperate mountain grasslands differing in land use. Glob Chang Biol 12:995-1006

Bitterlich W (1984) The relascope idea. Relative measurements in forestry. Commonwealth Agricultural Bureaux, Wallingford, Oxfordshire

Brown M, Black TA, Nesic Z et al (2010) Impact of mountain pine beetle on the net ecosystem production of lodgepole pine stands in British Columbia. Agric For Meteorol 150:254-264

Brown MG, Black TA, Nesic Z et al (2012) The carbon balance of two lodgepole pine stands recovering from mountain pine beetle attack in British Columbia. Agric For Meteorol 153: $82-93$

Brunner I, Bakker MR, Björk RG et al (2012) Fine-root turnover rates of European forests revisited: an analysis of data from sequential coring and ingrowth cores. Plant Soil 362:357372

Brunner I, Børja I, Dalsgaard L et al (2013) Belowground carbon turnover in European forests: Fine roots, mycorrhizal mycelia, soil organic matter and soil models. A technical report for national C reporters, LULUCF experts and ecosystem modellers. COST Action FP0803. Swiss Federal Institute for Forest, Snow and Landscape Research WSL, Birmensdorf, pp 81

Canadell JG, Raupach MR (2008) Managing forests for climate change mitigation. Science 320:1456-1457

Caprez R, Niklaus PA, Körner C (2012) Forest soil respiration reflects plant productivity across a temperature gradient in the Alps. Oecologia 170:1143-1154

De Wit HA, Palosuo T, Hylen G, Liski J (2006) A carbon budget of forest biomass and soils in southeast Norway calculated using a widely applicable method. For Ecol Manag 225:1526

Díaz-Pinés E, Schindlbacher A, Pfeffer M et al (2010) Root trenching: a useful tool to estimate autotrophic soil respiration? A case study in an Austrian mountain forest. Eur J For Res 129:101-109

Don A, Bärwolff M, Kalbitz K et al (2012) No rapid soil carbon loss after a windthrow event in the High Tatra. For Ecol Manag 276:239-246

Donoso PJ, Nyland RD (2006) Interference to hardwood regeneration in Northeastern North America: The effects of raspberries (Rubus spp.) following clearcutting and shelterwood methods. North J Appl For 23:288-296

Edburg SL, Hicke JA, Lawrence DM, Thornton PE (2011) Simulating coupled carbon and nitrogen dynamics following mountain pine beetle outbreaks in the western United States. J Geophys Res 116:G04033

Edburg SL, Hicke JA, Brooks PD et al (2012) Cascading impacts of bark beetle-caused tree mortality on coupled biogeophysical and biogeochemical processes. Front Ecol Environ 10:416-424

Elzhov TV, Mullen KM, Spiess A-N, Bolker B (2013) min-pack.lm: $\mathrm{R}$ interface to the Levenberg-Marquardt nonlinear leastsquares algorithm found in MINPACK, Plus Support for Bounds. https://cran.r-project.org/web/packages/minpack.lm. Accessed 15 Sept 2015

Finér L, Ohashi M, Noguchi K, Hirano Y (2011) Fine root production and turnover in forest ecosystems in relation to stand and environmental characteristics. For Ecol Manag 262: 2008-2023
Forrester JA, Mladenoff DJ, Gower ST (2013) Experimental manipulation of forest structure: near-term effects on gap and stand scale C dynamics. Ecosystems 16:1455-1472

Franklin JF, Spies TA, Van Pelt R et al (2002) Disturbances and structural development of natural forest ecosystems with silvicultural implications, using Douglas-fir forests as an example. For Ecol Manag 155:399-423

Gill RA, Jackson RB (2000) Global patterns of root turnover for terrestrial ecosystems. New Phytol 147:13-31

Goetz SJ, Bond-Lamberty B, Law BE et al (2012) Observations and assessment of forest carbon dynamics following disturbance in North America. J Geophys Res 117:G02022

Hansen EM (2013) Forest development and carbon dynamics after mountain pine beetle outbreaks. For Sci 60(3):476-488

Hanson PJ, Edwards NT, Garten CT, Andrews JA (2000) Separating root and soil microbial contributions to soil respiration: a review of methods and observations. Biogeochemistry 48:115-146

Helmisaari HS, Derome J, Nöjd P, Kukkola M (2007) Fine root biomass in relation to site and stand characteristics in Norway spruce and Scots pine stands. Tree Physiol 27:1493-1504

Högberg P, Nordgren A, Buchmann N et al (2001) Large-scale forest girdling shows that current photosynthesis drives soil respiration. Nature 411:789-792

Hülber K, Dirnböck T, Kleinbauer I et al (2008) Long-term impacts of nitrogen and sulphur deposition on forest floor vegetation in the Northern limestone Alps, Austria. Appl Veg Sci 11:395-404

Humphreys ER, Andrew Black T, Morgenstern K et al (2005) Net ecosystem production of a Douglas-fir stand for 3 years following clearcut harvesting. Glob Chang Biol 11:450-464

Janssens IA, Freibauer A, Ciais P et al (2003) Europe's terrestrial biosphere absorbs 7 to $12 \%$ of European anthropogenic $\mathrm{CO}_{2}$ emissions. Science 300:1538-1542

Kern CC, Reich PB, Montgomery RA, Strong TF (2012) Do deer and shrubs override canopy gap size effects on growth and survival of yellow birch, northern red oak, eastern white pine, and eastern hemlock seedlings? For Ecol Manag 267:134 143

Kindler R, Siemens J, Kaiser K et al (2011) Dissolved carbon leaching from soil is a crucial component of the net ecosystem carbon balance. Glob Chang Biol 17:1167-1185

Knohl A, Kolle O, Minayeva TY et al (2002) Carbon dioxide exchange of a Russian boreal forest after disturbance by wind throw. Glob Chang Biol 8:231-246

Knohl A, Søe ARB, Kutsch WL et al (2008) Representative estimates of soil and ecosystem respiration in an old beech forest. Plant Soil 302:189-202

Kobler J, Jandl R, Dirnböck T et al (2015) Effects of stand patchiness due to windthrow and bark beetle abatement measures on soil $\mathrm{CO}_{2}$ efflux and net ecosystem productivity of a managed temperate mountain forest. Eur J For Res 134: 683-692

Kolari P, Pumpanen J, Rannik Ü et al (2004) Carbon balance of different aged Scots pine forests in Southern Finland. Glob Chang Biol 10:1106-1119

Körner C (2003) Slow in, rapid out - carbon flux studies and Kyoto targets. Science 300:1242-1243

Köster K, Püttsepp Ü, Pumpanen J (2011) Comparison of soil $\mathrm{CO}_{2}$ flux between uncleared and cleared windthrow areas in Estonia and Latvia. For Ecol Manag 262:65-70 
Kowalski AS, Loustau D, Berbigier P et al (2004) Paired comparisons of carbon exchange between undisturbed and regenerating stands in four managed forests in Europe. Glob Chang Biol 10:1707-1723

Kramer K, Brang P, Bachofen $\mathrm{H}$ et al (2014) Site factors are more important than salvage logging for tree regeneration after wind disturbance in Central European forests. For Ecol Manag 331:116-128

Kurz WA, Dymond CC, Stinson G et al (2008) Mountain pine beetle and forest carbon feedback to climate change. Nature 452:987-990

Kuzyakov Y, Cheng W (2001) Photosynthesis controls of rhizosphere respiration and organic matter decomposition. Soil Biol Biochem 33:1915-1925

Luyssaert S, Inglima I, Jung $\mathrm{M}$ et al (2007) $\mathrm{CO}_{2}$ balance of boreal, temperate, and tropical forests derived from a global database. Glob Chang Biol 13:2509-2537

Máliš F, Konôpka B, Mal’ová M (2013) Post-harvest biomass stock and productivity of Calamagrostis epigejos community under beech and spruce forest stand. Lesn Cas For J 59:197202

Mathys A, Black TA, Nesic Z et al (2013) Carbon balance of a partially-harvested mixed conifer forest following mountain pine beetle attack and its comparison to a clearcut. Biogeosciences 10:5451-5463

Mayer M, Matthews B, Schindlbacher A, Katzensteiner K (2014) Soil $\mathrm{CO}_{2}$ efflux from mountainous windthrow areas: dynamics over 12 years post-disturbance. Biogeosciences 11:60816093

Mayer M, Sandén H, Rewald B, Godbold DL, Katzensteiner K (2017) Increase in heterotrophic soil respiration by temperature drives decline in soil organic carbon stocks after forest windthrow in a mountainous ecosystem. Funct Ecol 31: $1163-1172$

Mitchell SJ (2013) Wind as a natural disturbance agent in forests: a synthesis. Forestry 86:147-157

Moore DJP, Trahan NA, Wilkes P et al (2013) Persistent reduced ecosystem respiration after insect disturbance in high elevation forests. Ecol Lett 16:731-737

Morehouse K, Johns T, Kaye J, Kaye M (2008) Carbon and nitrogen cycling immediately following bark beetle outbreaks in southwestern ponderosa pine forests. For Ecol Manag 255:2698-2708

Naaf T, Wulf M (2007) Effects of gap size, light and herbivory on the herb layer vegetation in European beech forest gaps. For Ecol Manag 244:141-149

Nave LE, Vance ED, Swanston CW, Curtis PS (2010) Harvest impacts on soil carbon storage in temperate forests. For Ecol Manag 259:857-866

Neff JC, Asner GP (2001) Dissolved organic carbon in terrestrial ecosystems: synthesis and a model. Ecosystems 4:29-48

Odum EP (1969) The strategy of ecosystem development. Science 164:262-270

Ostonen I, Lõhmus K, Pajuste K (2005) Fine root biomass, production and its proportion of NPP in a fertile middle-aged Norway spruce forest: comparison of soil core and ingrowth core methods. For Ecol Manag 212:264-277

Palviainen M, Finér L, Kurka A-M et al (2004) Decomposition and nutrient release from logging residues after clear-cutting of mixed boreal forest. Plant Soil 263:53-67
Palviainen M, Finér L, Mannerkoski H et al (2005) Responses of ground vegetation species to clear-cutting in a boreal forest: aboveground biomass and nutrient contents during the first 7 years. Ecol Res 20:652-660

Perruchoud D, Kienast F, Kaufmann E, Bräker OU (1999) 20th century carbon budget of forest soils in the Alps. Ecosystems 2:320-337

Pfeifer EM, Hicke JA, Meddens AJH (2011) Observations and modeling of aboveground tree carbon stocks and fluxes following a bark beetle outbreak in the western United States. Glob Chang Biol 17:339-350

Pröll G, Darabant A, Gratzer G, Katzensteiner K (2015) Unfavourable microsites, competing vegetation and browsing restrict post-disturbance tree regeneration on extreme sites in the Northern Calcareous Alps. Eur J For Res 134: 293-308

Puettmann KJ, Wilson SM, Baker SC et al (2015) Silvicultural alternatives to conventional even-aged forest management what limits global adoption? For Ecosyst 2:8

Pysek P (1991) Biomass production and size structure of Calamagrostis villosa populations in different habitats. Presilia 63:9-20

R Core Team (2015) R: a language and environment for statistical computing http://www.R-project.org/. Accessed 11 Sept 2015

Reimoser F, Gossow H (1996) Impact of ungulates on forest vegetation and its dependence on the silvicultural system. For Ecol Manag 88:107-119

Reimoser F, Reimoser S (2010) Ungulates and their management in Austria. Eur Ungulates Their Manag 21st Century Camb Univ Press Camb, pp 338-356

Romme WH, Knight DH, Yavitt JB (1986) Mountain pine beetle outbreaks in the Rocky Mountains: regulators of primary productivity? Am Nat 484-494

Schatz JD, Forrester JA, Mladenoff DJ (2012) Spatial patterns of soil surface $\mathrm{C}$ flux in experimental canopy gaps. Ecosystems 15:616-623

Schindlbacher A, Zechmeister-Boltenstern S, Jandl R (2009) Carbon losses due to soil warming: do autotrophic and heterotrophic soil respiration respond equally? Glob Chang Biol 15:901-913

Schindlbacher A, Jandl R, Schindlbacher S (2014) Natural variations in snow cover do not affect the annual soil $\mathrm{CO}_{2}$ efflux from a mid-elevation temperate forest. Glob Chang Biol 20: $622-632$

Schindlbacher A, Borken W, Djukic I et al (2015) Contribution of carbonate weathering to the $\mathrm{CO} 2$ efflux from temperate forest soils. Biogeochemistry 124:273-290

Schinner F, Öhlinger T, Kandeler E, Margesin R (1996) Methods in soil biology. Springer, Berlin [u.a]

Schlesinger WH (1991) Biogeochemistry: an analysis of global change. Acad. Press, San Diego [u.a]

Schodterer H (2011) Verjüngung im österreichischen Wald: Defizite im Schutzwald. BFW-Praxisinformation 24, pp $10-14$

Seidl R, Rammer W, Spies TA (2014a) Disturbance legacies increase the resilience of forest ecosystem structure, composition, and functioning. Ecol Appl 24:2063-2077

Seidl R, Schelhaas M-J, Rammer W, Verkerk PJ (2014b) Increasing forest disturbances in Europe and their impact on carbon storage. Nat Clim Chang 4:806-810 
Senf C, Pflugmacher D, Hostert P, Seidl R (2017) Using Landsat time series for characterizing forest disturbance dynamics in the coupled human and natural systems of Central Europe. ISPRS J Photogramm Remote Sens 130: 453-463

Solly E, Schöning I, Boch S et al (2013) Mean age of carbon in fine roots from temperate forests and grasslands with different management. Biogeosciences 10:4833-4843

Subke J-A, Inglima I, Francesca Cotrufo M (2006) Trends and methodological impacts in soil $\mathrm{CO}_{2}$ efflux partitioning: a metaanalytical review. Glob Chang Biol 12:921-943

Swanson ME, Franklin JF, Beschta RL, Crisafulli CM, Della Salla DA, Hutto RL, Lindenmayer DB, Swanson FJ (2011) The forgotten stage of forest succession: early-successional ecosystems on forest sites. Front Ecol Environ 9:117-125

Takagi K, Fukuzawa K, Liang $\mathrm{N}$ et al (2009) Change in $\mathrm{CO}_{2}$ balance under a series of forestry activities in a cooltemperate mixed forest with dense undergrowth. Glob Chang Biol 15:1275-1288

Thom D, Rammer W, Dirnböck T, Müller J, Kobler J, Katzensteiner K, Helm N, Seidl R (2017) The impacts of climate change and disturbance on spatio-temporal trajectories of biodiversity in a temperate forest landscape. J Appl Ecol 54:28-38
Vogt KA, Persson H (1991) Measuring growth and development of roots. In: Techniques and approaches in forest tree ecophysiology. CRC Press, Boca Raton, pp 477-501

Wan S, Luo Y (2003) Substrate regulation of soil respiration in a tallgrass prairie: results of a clipping and shading experiment. Glob Biogeochem Cycles 17:1054

Williams CA, Vanderhoof MK, Khomik M, Ghimire B (2014) Post-clearcut dynamics of carbon, water and energy exchanges in a midlatitude temperate, deciduous broadleaf forest environment. Glob Chang Biol 20:992-1007

WRB (2006) World reference base for soil resources 2006. vol 2nd edition. World Soil Resources Reports No. 103. FAO Rome

Wu Y, Wu J, Deng Y et al (2011) Comprehensive assessments of root biomass and production in a Kobresia humilis meadow on the Qinghai-Tibetan Plateau. Plant Soil 338:497-510

Zerva A, Mencuccini M (2005) Short-term effects of clearfelling on soil $\mathrm{CO}_{2}, \mathrm{CH}_{4}$, and $\mathrm{N}_{2} \mathrm{O}$ fluxes in a Sitka spruce plantation. Soil Biol Biochem 37:2025-2036

Zhou X, Wan S, Luo Y (2007) Source components and interannual variability of soil $\mathrm{CO}_{2}$ efflux under experimental warming and clipping in a grassland ecosystem. Glob Chang Biol 13: 761-775 